\title{
La Misión Poética de César Tiempo
}

César Tiempo es el seudónimo de Israel Zeitlin, argentino nacido en Ucrania en 1906. La familia Zeitlin, huyendo de un pogrom, se trasladó a Hamburgo, donde se embarcó para América. El vapor llegó a Nueva York, pero nuestras autoridades de inmigración no quisieron acoger a la familia Zeitlin, que tuvo que continuar el viaje: hasta Buenos Aires. Así es que perdimos nosotros un poeta judío. y se ganó la Argentina un poeţa judío y nacional. Israel Zeitlin hutbiera sido un poeta judío en cualquier país, pero se ha hecho, en la Argentina, no sólo un poeta de su raza, sino de su patria también.

Los escritores judíos han desempeñado un papel muy importante en la literatura argentina del siglo $\mathrm{xx}$, y lo más interesante es que esta participación no viene de los judíos sefardíes que siguen, desde hace siglos, las tradiciones judíoespañolas de la península. E1 grupo argentino es de ascendencia judíorusa, hijos de emigrados, o emigrados ellos mismos, como César Tiempo, que han venido al Nuevo Mundo buscando asilo y libertad. Traídos a la Argentina, a principios de este siglo, por la magnanimidad del barón Moisés Hirsch, de Austria, que adquirió una gran extensión de terreno en la Provincia de Entre Ríos, dichos judíos rusos formaron colonias que muy pronto aportaron su contribución a la vida económica de su nueva patria.

Y no sólo económica. Lo que de veras asombra es la rapidez con que algunos de estos emigrados tan recientes se incorporaron a la vida literaria de Argentina. A pesar de sus tradiciones literarias, tan distintas a las de tal país, y no obstante las tremendas dificultades lingüísticas, de estos emigrados y de sus hijos ha surgido una: literatura que responde a su ansia de contar su historia y sus sufri- 
mientos, a una necesidad de explicarse ante sus hermanos nuevos, y a un deber de agradecimiento hacia la nación, que les ofreció la oportunidad de vivir como hombres libres.

Las figuras más destacadas del florecimiento judio en la literatura argentina son Alberto Gerchunoff, Samuel Glusberg, Samuel Eichelbaum y César Tiempo. Gerchunoff es el que tiene quizás más prestigio, por sus trabajos editoriales en La Nación de Buenos Aires, sus dos colecciones de cuentos Los gauchos judíos y Cंuentos de ayer, $\mathrm{y}$ una serie de obras críticas y filosóficas que le dieron un puesto entre los más altos de la intelectualidad porteña. Samuel Glusberg ha contribuido mucho a la difusión de las letras argentinas con su Editorial Babel, y con sus novelas y cuentos, escritos bajo el seudónimo de Enrique Espinoza. Samuel Eichelbaum ha escrito cuentos y crítica, pero su mayor fama proviene de su producción teatral. Sus dramas psicológicos merecieron elogios unánimes de los críticos, y el puesto de primer dramaturgo argentino, si no es que continental.

Entre estos autores y otros muchos dignos de mencionar, si hubiera tiempo, ninguno ha obrado con mayor diligencia y éxito que César Tiempo. Más que ningún otro, él se ha hecho el intérprete, el defensor y la conciencia de los judíos porteños. Como director de los periódicos Crítica y El Sol, y de la revista literaria La Columna, Tiempo abrió sus páginas a los jóvenes escritores judíos, $\mathrm{y}$ ha luchado por la independencia y la sinceridad, justificando siempre el noble lema de la revista: "Dispuestos a todos los sacrificios, menos al sacrificio de la verdad." Hizo lo posible por combatir el infame programa antisemita inspirado por Hugo Wast hace varios años, programa e inspirador que gozan actualmente del apoyo oficial del gobierno argentino, que da, con tal apoyo y con las consectentes persecuciones, la prueba definitiva de su barbarie.

En su obra dramática y poética, César Tiempo continúa y refuerza su misión de campeón e intérprete judío. Ha estrenado dos dramas, El teatro soy yo y Pan Criollo, ambos de alto valor artístico y atun poético, y que trataron cuestiones raciales con imponente nobleza y sinceridad. Pero Tiempo es, ante todo, poeta, y en sus poemas se ve más claramente su doble misión de intérprete y campeón.

Su primer libro de poesías, Versos de una ..., fué publicado en 1923. La crítica lo acogió con alabanzas y luego con asombro al saber que su autor tenía sólo diez y siete años y que su dominio del caste- 
llano era cosa tan reciente. Por su segunda colección de poesías, Libro para la pausa del sábado, recibió el Primer Premio Municipal de Poesía en 1930. Desde entonces ha publicado otras dos colecciones: Sabatión argentino, en 1933, y Sábadomingo, en 1938.

¿Cuáles son los temas de la poesía de César Tiempo? Como intérprete de su raza, nos habla del sábado judío, del cariño de la familia, de las niñas judias, de la vida del ghetto bonaerense. Como defensor y campeón de los judíos, nos habla de los pogroms, de los. sufrimientos de sus antepasados, nos hace alzar la vista hacia la grandeza de la tradición judía, y castiga con el azote de'su ironía a sus hermanos cuando olvidan esta grandeza por sus preocupaciones. mezquinas y vulgares.

Su tema principal es el sábado, de pausa y de meditación, día sagrado en que los judios, apartando la vista de las inquietudes diarias, dejan el bullicio de la calle para recogerse en la sinagoga y en el hogar, contemplando, ante el candelabro de los siete brazos, la gloria eterna de Dios. A tal pausa sabática se refieren, como ya hemos visto, los títulos de tres de sus libros de poesía: Libro para la pausa del sábado, Sábadomingo y Sabatión argentino. Este se refiere al mito del río Sabatión, cuyas aguas dejan de fluir en el día santo del reposo. En un lenguaje de emoción religiosa, su poesía, hecha salmo, canta la tristeza y añoranza del alma judía, llena de recuerdos. En "Sábado nuestro", dice el poeta:

Sábado nuestro, ruta del festivo reposo, candelabros de llamas densas como mis días custodian tu abandono de ventanas sombrías como a un niño en la noche, solitario y medroso ...

y en "Nacimiento del sábado":

Sábado de la pausa - schabbat-, del armisticio,

de la renoviación - chadasch--, de luna

nueva - neomenia- para la fortuna

de quien aspira, lejos del bullicio,

buscar asilo en la misericordia

del ocio activo, de la paz sagrada,

y de espaldas a vértigo y discordia

amar a Dios y no pensar en nada.

En este poema vemos lo mucho que le atraen al poeta las palabras hebreas, sobre todo las palabras rituales, como schabbat, sábado; 
chadasch, renovación; moles, canto fúnebre; thaléisem, especie de estola.

En su "Himno de las muchachas judías", dice:

Contra el fantasma de la guerra

con una misma fe tenaz

demos un sábado a la tierra.

Sábado es paz. Sábado es paz...

y por último, su "Oración" invoca la serenidad y la paz de la "Luna, madre del Sábado" y la luz de "Domingo, hijo del sol", porque

Sábadomingo, el niño nuevo como la danza que muere y que renace sobre la tierra herida, llega con su esperanza a buscar tu esperanza, una madre judía con su amor te lo alcanza, dale tu claridad para toda la vida.

En otros poemas, César Tiempo canta la alegría muy argentina de la vida de los otros días de la semana. No olvidemos que el pueblo judío es tan amigo de la calle como el pueblo griego. $Y$ este interés en la vida total y exterior, este infinito buen humor, esta tremenda capacidad para reaccionar contra la tristeza e incertidumbre de la existencia los ha expresado el poeta en versos rebosantes del puro gozo de vivir. En "Lluvia con sol en el ghetto", por ejemplo, dice :
¡Aleluya! : Aleluya!
ríe el sol en la lluvia.
Lluvia rubia y festiva
sobre la judería.
Aleluya que hermanas
voz semita y cristiana.
Cantan vivos colores
los tardíos Lacrozes. *
La alegría del ghetto
se da cita en el cielo.

\author{
En Junín y Lavalle \\ luce moño la tarde. \\ Lluvia alegre y dorada \\ para amar sin palabras... \\ Vuelca Dios sobre todos \\ tenue ceniza de oro. \\ Moza, dame la mano, \\ corramos a mojarnos. \\ ¡Aleluya! ; Aleluya! \\ ríe el sol en la lluvia.
}

Buen ejemplo es éste del humorismo de Tiempo, que se encuentra con frecuencia en su poesía, humorismo teñido de ironía en muchos poemas - aunque no en éste por los temas que trata. Pero cuando

* Lacrozes son los verdes tranyías que pasan por las calles Junín y Lavalle del ghetto. 
recuerda los pogroms de Europa, nos habla con acento en que no entra más que la ira y la terrible ironía de su honda emoción:

Mientras la noche marinera

lanza su gorra al cielo oscuro danzan las sombras de la hoguera sobre el espejo atroz del muro. Danza la rubia espiga abierta, danza la abuela del pan puro, llama el terror de puerta en puerta hasta el patíbulo del muro... Danza la turba desatada, rueda el pavor - bola de nieve-. Dios tiene la boca cerrada y el cielo, ahora, llueve, llueve.
Danza la pobre madre pobre sola y sin luz en el desierto, mientras la llavia cae sobre su niño muerto, muerto, muerto. En la ciudad la luz desciende, sobre el asfalto de piel lucia, marca al que compra y al que vende y danza sobre su alma sucia. Danzan las tres palabràs de $1 a$ sentencia sobre el muro atroz, detrás del tiempo el hombre vela mientras Dios duerme como Dios.

E1 poeta logra aquí un efecto conmovedor con su repetición de palabras, artificio que le servirá admirablemente en el poema "Llorando y cantando", que citaremos más tarde.

$\mathrm{Su}$ ira contra los opresores de' los judíos puede convertirse en azote con el cual castiga a los judíos mismos cuando merecen tal castigo, por su mundanalidad e ignorancia. En su magnífica "Arenga en la muerte de Jáim Najman Biálik", haciendo el contraste entre la vida y muerte del ilustre poeta hebreo y la indiferencia de los judíos porteños, Tiempo dice a éstos:

Señores burgueses que infringís todos los Mandamientos

y estáis los sábados sobre vuestros libros de tapas negras

pasándoles la mano por el lomo a las cifras

para que se alarguen como gatos,

os he visto en los templos resplandecientes

-apartados como los purs sangs en los bretes suntuosos-

con los ojillos redondos y desvaídos

y las altas galeras y los thaléisem de seda pura.

queriendo sobornar a Dios

que os conoce mejor que vuestros empleados.

Jáim Najman Biálik ha muerto.

Ante una sociedad humana que se niega tercamente a recibir a los judíos como compatriotas o a darles la ansiada patria prometida por la Declaración Balfour, César Tiempo, expresa su ironía en "Cementerio israelita": 


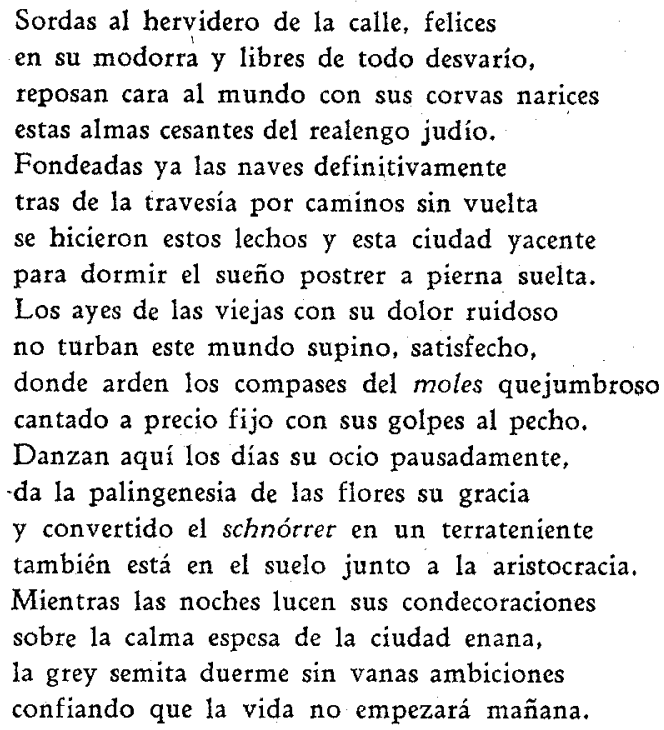

En la imagen de los judíos muertos que "reposan cara al mundo con sus corvas narices" hay un admirable ejemplo de la mezcla de htmor y ternura que es característica notable de la poesía de. Tiempo. La ironía de tener que esperar la muerte antes de convertirse en terrateniente y de yacer en el mismo elemento que habita la aristocracia, esta ironía se realza con el lema que usó Tiempo para su poema, una cita de Lord Balfour: "A national home for the Jewrish people."

La poesía de César Tiempo es de espíritu muy hebraico. Tiene las cualidades que se advierten en la obra de los mejores poetas hebreos: ironía, humorismo, sentimiento, piedad, un interés en el hombre y en la realidad de su existencia, todo expresado con un lirismo franco y puro. $Y$ al mismo tiempo, esta poesía hebrea de César Tiempo resulta ser muy castiza en la forma. Hay en sus cantares una contagiosa alegría coral y en sus salmos la lentitud y la paz del canto llano medieval. Cualidades muy españolas son su humor y su ternura, que a veces se convierten en amargura y sarcasmo. Tiene un pudor muy español, que puede aceptar estoicamente los azares de la vida y contemplar con ecuanimidad los dolores más hondos. Muy español también es su amor a lo preciso y concreto, y esa fantasía poética que junta elementos muy desemejantes e improbables en 
metáforas e imágenes osadas y justas. Así, estos versos descriptivos: "Banderas de humo los tejados izan", "E1 frío / aguza sus puñales en el viento"; "Viernes húmedo. El alba / tiene un pañuelo en cada mano", "La noche está de espaldas al cielo", "Viernes que llevas en tus brazos / al sábado como a una esposa, / - Israel cuenta por ocasos / y se anticipa a las auroras-", "Desanuda el domingo nervioso su corbata / y la sombra de lunes avanza indiferente." $Y$ hablando de un poeta que sueña con riquezas:

$$
\begin{aligned}
& \text { Construyo paraísos burgueses } \\
& \text { y estoy abajo sin un cobre } \\
& \text { ¡pobre yentura la del pobre } \\
& \text { cuando los sueños hacen eses: }
\end{aligned}
$$

y esto, de una elegía en la muerte de un pintor sordomudo:

$$
\begin{aligned}
& \text { Tus manos aprendieron el lenguaje más puro } \\
& \text { traduciendo en imágenes tu dolor sin palabras, } \\
& \text { así como las nubes dicen sencillamente } \\
& \text { su congoja pluviátil con imágenes de agua. }
\end{aligned}
$$

En esta hora tan trágica de un mundo lleno de sangre, de rencor y de intolerancia, es bueno escuchar la voz de un poeta judío, miembro de esta raza tan calumniada. Sabiendo que comprender es perdonar, César Tiempo se dedica a revelarnos el alma de su raza, ahuyentando así las equivocaciones y los engaños que nutren la intolerancia. La Argentina y la América entera necesitan tales voces, ahora más que nunca.

$\mathrm{Y}$ a pesar de los increíbles horrores e injusticias que se han cometido, y que se cometen actualmente, contra los judíos, el poeta nos da, a sus hermanos judíos y al mundo entero, una nota de esperanza en el último poema de su libro Sábadomingo, poema intitulado "Llorando y cantando", y que tiene este lema sacado de los salmos: "Los que siembran 1lorando cantando cosecharán":

De un pais de leche y miel, de colinas y ríos claros salió el pueblo de Israel llorando.

Columnas de fuego y nubes sus pasos fueron guiando e Israel cruzó el desierto llorando.

Los cautivos levantaron ciudades de muras altos y dieron gracias a Dios llorando. 
Las lanzas se hicieron rastras $y$ las espadas arados, trabajaron noche $y$ día llorando.

El mar de aguas encendidas pasaton con sus caballos, los encontró la borrasca llorando.

Estuvieron en los ghettos sombríos emparedados, pero encontraron la luz llorando.
El sábado fué su escudo, su isla, su candelabro, y bendijeron el sábado llorando.

Vejados y escarnecidos, sobre la tierra encorvados, siembran $\sin$ odio $y \sin$ tregua llorando.

Mañana el sol sonteirá sobre los campos sembrados $y$ entonces cosecharemos cantando, hermanos, cantando.

Donald D. WALsh, The Choate School, Wallingford, Connecticut. 